\title{
NOTES ON THE SPIDER FAUNA OF NEW ENGLAND
}

\author{
By Elizabeth B. Bryant
}

Museum of Comparative Zoology, Cambridge, Mass.

Nowhere, perhaps, in the New World, has the spider fauna of an equal area been more intensively studied than that of New England.

One of the first students of American arachnology was Nicholas Marcellus Hentz, (1797-1856). While confining himself chiefly to the study of spiders of Alabama and North Carolina, he received much material from his friend and correspondant, the well known New England entomologist, Thaddeus William Harris, (1795-1856). As was the custom of his time, Hentz wrote very brief descriptions, reliance being placed upon his colored drawings for ultimate identification. He described few new genera and distributed his species among the genera then known to Europe. From time to time, his papers were published in the Journal of the Boston Society of Natural History, covering the period from 1842 to 1867 . Subsequent to the death of Hentz, the secretary of the Society, Edward Burgess, assisted by James H. Emerton, assembled these scattered records, and together with some few additions by Emerton, they were published in 1875 as the second volume of the Occasional Papers of the Society. The collections of Hentz, including his types, were dried and mounted on pins, in the manner of entomological specimens, with the result that today little remains but the labels in faded ink. The collection, together with his notes and such drawings as had not been distributed as souvenirs, became the property of the Boston Society, the present custodian.

The first to devote his entire attention exclusively to the New England region as a unit, was James H. Emerton, (1847-1931). When or why Emerton, who was a draftsman by training and of an artistic temperament by nature, be- 
came interested in the study of spiders is a matter of speculation. However, as early as 1874 , he was evidently familiar with a paper by the Rev. Octavius Pickhard-Cambridge, (1828-1917), of Devonshire, England, on certain minute European spiders, since early that same year he sent a collection of similar New England forms to Cambridge for study and identification. All these American forms were recognized as new and were described and figured by Cambridge in the Proceedings of the London Zoölogical Society for that year, 1874. A second collection of similar material was sent by Emerton to Cambridge and was described and figured in the same journal in 1875 . There can be little doubt that with Hentz as a model, Emerton made colored drawings of his material quite early. These have never been published.

In 1875 , Emerton went abroad, taking with him a portion of his New England material. Some time was passed at Leipzig and Jena in study but he continued to collect in the surrounding country. Later, in France, he met Eugene Simon, (1848-1924), who was to become the foremost arachnologist of his time. From this contact, a life long friendship began. Together they made collecting excursions in the vicinity of Paris, and many specimens from Simon were added to Emerton's European collection, including material from the Pyrenees and Corsica recently described by Simon.

As early as 1864, Simon, then sixteen years of age, had published a comprehensive work on spiders under the title of "Histoire Naturelle des Araignées" and was already occupied with his monumental "Les Arachnides de France" dating from the year 1874. It is perhaps to Simon's example and probable suggestion, that we are indebted for one of the least known of Emerton's writings, "A Comparison of the Spiders of Europe and North America", a short paper published in 1877, in the Proceedings of the Boston Society of Natural History, vol. XIX. In 1882, the first of his systematic studies, "The New England Spiders of the Family Theridiidæ" appeared in the Transactions of the Connecticut Academy of Arts and Sciences. The series was continued at irregular intervals in the same publication until 1915.

In 1904, the Boston Society of Natural History published 
the first issue of its "Fauna of New England"; the ninth in the series, entitled "A List of the Aranea" appeared in April 1908. This listed 399 species. At the present time, 612 species have been reported, an increase of over $50 \%$. Of these, Emerton has described 214 species, or over one third.

Since a comparison of the faunal lists of regions of similarly intensive study may have some interest, the following tabulation is included.

$\begin{array}{lccll} & \begin{array}{c}\text { Approx area } \\ \text { (in sq. miles) }\end{array} & \text { Species } & \text { Authority } & \text { Year } \\ \text { New England } & 65,000 & 612 & \text { Bryant } & 1941 \\ \text { New York } & 49,000 & 551 & \text { Crosby \& Bishop } & 1928 \\ \text { Great Britain } & 89,000 & 556 & \text { Bristowe } & 1939\end{array}$

Possibly rather more than $10 \%$ of the spider fauna of New England is common to Europe. A number of species seemingly introduced by commerce have been established; such are Theridion tepidariorum C. Koch; Scytodes thoracica Latreille; and Pholcus phalangioides (Fuesslin.), all common house spiders. Others, probably circumpolar, are found across the continent but do not extend very far south. Of these we may mention Cyclosa conica (Pallas), Aranea angulata Linn., Salticus senicus (Linn.), Zelotes subterraneous (C. Koch). Of especial interest, is the discovery of Cercidia prominens (Westring), a northern Eurasian species, in a cold swamp in Holliston, Massachusetts, a locality from which several insects peculiar to the far north have been taken. This species also occurs in northern New England.

The following includes a description of one new species, two new names, a description of a European species new to New England, and new records of localities and a few corrections.

\section{FAMILY OECOBIIDAE}

Genus Tapinesthis Simon 1914.

\section{Tapinesthis inermis (Simon)}

Ö̈nops inermis Simon, Ann. Soc. Ent. France, 1882, (6), $2: 240$.

Orchestina saltitans Emerton, nec Banks, Trans. Conn. Acad., 1909, 14 : 214, pl. 1, fig. 4. 
Tapinesthis inermis Dalmas, Ann. Soc. Ent. France, 1916, $85: 242$.

A pair of very small spiders was found in the basement of the museum of Natural History and figured by $\mathrm{Mr}$. Emerton in 1909. Probably because they are very small and had but six eyes, he identified them as Orchestina saltitans Banks, the only six-eyed spider found in the north. Today, they are discolored by age and badly broken but it is evident that the do not belong to the genus Orchestina but, as Comte de Dalmas suggests, they may be Tapinesthis inermis, a species found in southern France.

\section{Genus Orchestina Simon 1882}

\section{Orchestina saltitans Banks}

Orchestina saltitans Banks, Ent. News, 1894, 5 : 300.

Orchestina saltabunda Petrunkevitch, nec Simon, Ann. N. Y. Acad. Sci., 1910, $19:$ 207, pl. 21, figs. 2, 3.

Orchestina saltitans de Dalmas, Ann. Soc. Ent. France, 1916, 85 : 240, figs. 35, 36.

These minute spiders $(0: 8 \mathrm{~mm}$.) are not often found in collections, probably because they are so small and colorless. They move very rapidly and because of the large femur of the fourth pair of legs, they can jump a great distance compared to their small size. A pair was found jumping on a window sill in Boston and they are not uncommon in southern Connecticut. The genus is based on a species from Corsica. Three more species are known from the Mediterranean area but Orchestina saltitans is the only species reported from North America.

FAMILY AGELENID $\approx$

\section{SUBFAMILY HAHNIN $\approx$}

Genus Hahnia C. Koch 1841

Hahnia monticola sp. nov. (Fig. 1)

Female. Length, $2.3 \mathrm{~mm}$., ceph. $1.0 \mathrm{~mm}$, abd. $1.6 \mathrm{~mm}$.

Cephalothorax pale yellowish-brown, shining, slightly darker about margin, black about the eyes, anterior margin less than half the greatest width, thoracic groove faint; eyes, anterior row almost straight, a.m.e. smallest of the eight, almost touching, posterior row longer than anterior, pro- 
curved, eyes subequal, p.m.e. separated by almost a diameter and a half and from p.l.e. by a radius, lateral eyes touching; quadrangle of median eyes much narrower in front and as high as wide; clypeus below a.m.e. equals about a diameter of p.l.e.; mandibles vertical, attenuate, fang groove very short; labium as wide as long; maxillae twice as long as labium; sternum three-quarters as wide as long, heart-shaped, fourth coxae separated by more than a dia-
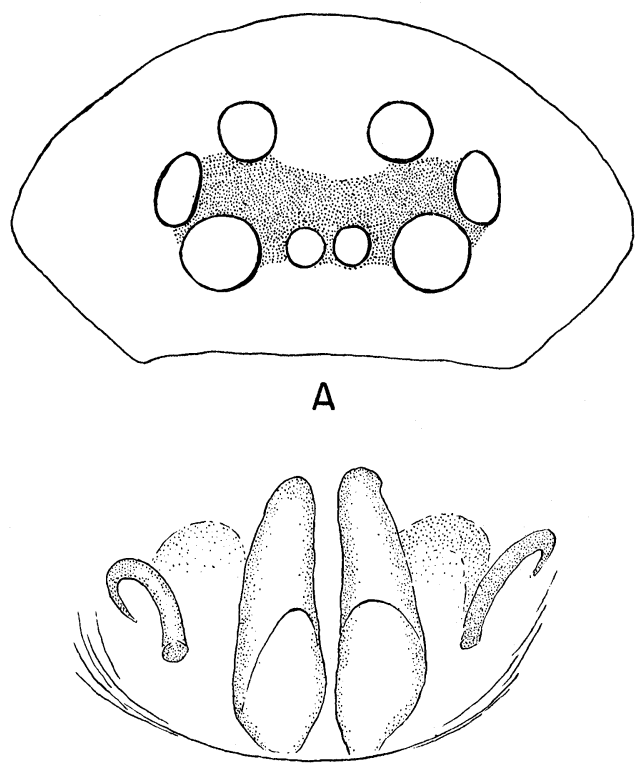

B

Figure 1. Hahnia monticola sp. nov. A, eyes; B, epigynum.

meter and sternum ending in an obtuse knob between, widest between second coxae, slightly convex, smooth; abdomen oval, widest on posterior half, flesh color with no markings, venter paler, opening of spiracle nearer spinnerets than to genital furrow, spinnerets in a straight line, distal joint of lateral spinnerets about half the length of basal joint, second pair with basal joint longer than that of lateral, distal joint very short, median pair separated by less than half a diameter; legs pale yellow, slender with a few weak spines; 
epigynum showing two pairs of dark tubes beneath the skin, the median pair much the larger, decreasing in size, and slightly diverging, the lateral pair much smaller and curved.

Holotype + New Hampshire; Mt. Washington, 5,000 feet, 1 July 1926, (Banks).

Paratype $\&$ New Hampshire; Mt. Washington, 5,000 feet, 1 July 1926, (Banks).

This species lacks the abdominal pattern found on Hahnia cinerea, the anterior row of eyes is almost straight, the eyes are closely grouped and the epigynum is very unlike that species.

\section{FAMILY PISAURID}

\section{Genus Dapanus Hentz 1867}

Recently Mr. Banks has called to my attention a name proposed by Hentz that has been overlooked by recent students. In 1867, "A Supplement to the Descriptions and Figures of the Araneides of the United States", was posthumously published in the Proc. Boston Soc. Nat. Hist., vol. 11:103-111, with two plates, from notes and figures by Hentz. In the volume of the Occ. Papers Boston Soc. Nat. Hist., vol. 2, 1875, which contains the collected writings of Hentz and is commonly used, these notes are distributed, always in brackets, to the original descriptions, and in the introduction a brief note states the origin. On page 44 of the Occ. Papers under Micrommata marmorata, appears the following: "Prof. Hentz had formerly considered this to be the type of a new subgenus, for which he gave the name Dapanus, distinguished by having its second pair of legs longest, the eyes subequal, the hinder row curved posteriorly. Supplement."

Micrommata marmorata is based on an adult female with a cocoon and is usually recognized as a synonym of Micrommata undata described on the preceding page. Mr. Emerton unfortunately placed the species in the genus Ocyale Audouin, (Lycosidae) and in 1898, Simon erected the genus Pisaurina for Dolomedes mirus Walck., (Ins. Apt., 1837, $1: 357$, for Abbot's drawing pl. 65, fig. 321). This is usually recognized as the same as undata Hentz; so the species formerly known as Pisaurina mira (Walck.) with its many synonyms becomes Dapanus mirus (Walck.) 
FAMILY THERIDIIDAE

Genus Nesticus Thorell 1870

Nesticus cellulanus (Oliv.)

Aranea cellulanus Olivier, Araignée, Encycl. Method., 1789, 4: 211.

Araneus cellulanus Clerck, Aranei suecici, 1757, p. 62 , pl. 4 , fig. 12.

Theridion terrestre Emerton, Psyche, 1924, 31:140, fig. 1. 우

A female of this European house spider was found out of doors at Holliston by Mr. Emerton. Later a male was found in Nova Scotia and it was recognized then as the European species. The position of the genus is very uncertain. As it has a distinct comb on the fourth tarsus, it has been placed by many in the Theridiidr, the only family with this character. But it also has a huge paracymbium, a character confined to the Linyphiidæx and the Argiopidx. It does not make a round web.

\section{Genus Conopistha Karsch 1881}

The genus Argyrodes was established by Simon in 1864 , in the first edition of the Histoire Naturelle des Araignées, p. 253, for a small species found about the Mediterranean. Unfortunately, the name has been used by Guenée in 1845, for a genus of Micro-Lepidoptera. In 1928, Strand published "Miscellanea nomenclatorica Zoologica et palaeontologica" in the Arch. Naturgesch. Berlin, 92, A. Heft 8, pp. 30-75 and proposed Argyrodina for Argyrodes. But Karsch, in 1881, (Diagn. Japonicæ, Berliner ent. Zeitschr.) erected the genus Conopistha for the Japanese species bona-dea, a new species. Later, Bösenberg and Strand placed this species in Argyrodes, (Japanische Spinnen, Abd. Senckenb. Ges., 1906, $30: 129$.). The name Conopistha has priority over Argyrodina.

The genus is very wide spread. The species are small, and both sexes are usually an iridescent silver. They live in the webs of larger spiders and catch small flies that escape the larger mesh. Two species of the genus are found in New England, cancellatus Hentz and trigonum Hentz. 


\section{FAMILY LINYPHIID E \\ SUBFAMILY LOPHOCARENINA \\ Genus Floricomus Crosby and Bishop 1925}

Floricomus emertoni nom. nov.

Histagonia nasuta Emerton, Trans. Conn. Acad., 1911, 16: 390, pl. 1, fig. 9, name preoccupied by Simon, Hist. Nat. Araignées, 1894, 1:583.

Floricomus nasuta Bishop and Crosby, Journ. N. Y. Ent. Soc., 1935, 43: 33, figs. 7-11.

The genus Histagonia was based by Simon in 1894, on a small species found in Africa. In his preliminary remarks, he placed in the genus, a species to which he refers as Pholcomma nasutum Emerton. His use of the name nasutum was obviously a lapsus calami, although it was used four times, for the reference to the Trans. Conn. Acad., 1882, 6: 30, shows that he intended Pholcomma rostratum Emerton. This was overlooked by Emerton, when he described a new species in 1911 and again by Bishop and Crosby when they revised the genus Floricomus in 1935. I propose the name emertoni for Histagonia nasuta Emerton, 1911.

FAMILY ARgIOPIDE

SUbFAmily ARANEINAE

Genus Aranea Linneus 1758

Aranea juniperi (Emerton)

Epeira juniperi Emerton, Trans. Conn. Acad., 1884, $6: 313$, pl. 34 , fig. 6 , pl. 36 , figs. $14,15,16$; ibid. 1909 , $14: 200$, pl. 5 , fig. 1 .

This species was described from a female found on an island in Portland Harbor, Maine. The male was not found until several years later. Mr. Emerton then figured the male and the first and second pairs of legs. Unfortunately, he confused the position of the spines on the femora and shows them as ventral, rather than prolateral. This in some genera is of minor importance, but the genus Aranea, (Eperia) is divided by the presence or absence of ventral spines on the anterior femora. Aranea juniperi has no ventral spines on 
the anterior femora and has two spines on the patella of the palpus. The species is widely distributed from Maine to Florida and west to Missouri. As it is small, delicate in both form and color, it is easily overlooked and is not often found in collections.

\section{FAMILY THOMISID \\ SUBFAMILY PhILODROMIN \\ Genus Thanatus C. Koch 1837 \\ Thanatus peninsulanus Banks}

Thanatus peninsulanus Banks, Proc. Cal. Acad., 1898, (3) , $1: 265$, pl. 16, fig. 11 ; Gertsch, Amer. Mus. Nov., 1935, no. $792: 25$.

Thanatus coloradensis Emerton, Ent. News, 1918, $29: 74$.

Thanatus retentus Chamberlin, Pomona Coll. Journ. Ent. and Zool., 1919, 12:9, pl. 6, fig. 5 .

In the fall of 1914, Mr. Emerton found this spider in a restaurant in Boston and identified it as Thanatus coloradensis Thorell. A few years ago, an adult male was found in the store room of a restaurant in Cambridge. It had evidently been introduced with boxes of fruit from southern California and as far as known, it never has been found out of doors in New England. The species has a wide distribution from southern California as far south as Peru, South America.

\section{FAMILY CLUBIONIDÆE \\ SubFamily Clubioninæ \\ Genus Clubiona Latreille 1804 \\ Clubiona bryantæ Gertsch}

Clubiona bryantæ Gertsch, Amer. Mus. Nov.; 1941, no. 1148:16.

Clubiona agrestris Emerton, Psyche, 1924, 31: 144, fig. 6, nec Clubiona? agrestris Hentz, 1847.

I had intended to rename this species but Dr. Gertsch also discovered the error and has renamed it in a recent paper. The species is known only from the type specimens found at Holliston, Massachusetts and a pair from Conway, 
Michigan. It probably is local and becomes adult early in the season. The two large hooks on the dorsal side of the tibia of the palpus are very characteristic.

\section{SUbFAMILY MICARIIN}

\section{Genus Micaria Westring 1851}

Micaria delicatula nom. nov.

Micaria aurata Bryant, Occ. Pap. Boston Soc. Nat. Hist. 1908, 7, no. 9 : 74, nec Micaria aurata (Canestrini), 1868, from Corsica.

Micaria aurata Gertsch, Amer. Mus. Nov., 1933, no. 637: 2 , figs 4,6 .

Micaria aurata Kaston, Check-list of the Spiders of Connecticut, 1938, p. 194.

This brilliant spider was wrongly synonomized in the New England List of Spiders in 1908 and unfortunately later workers have continued the error. The original description of Herpyllus auratus Hentz is rather vague, but the brilliant color and the two pairs of lateral bars on the anterior half of the abdomen is emphasized. In the south, there is found a Castianeira with similar markings which probably is the spider that Hentz had, as the figure shows the head only slightly narrowed, a character found in Castianeira, rather than Micaria and no indication of an abdominal constriction that is usually found in Micaria.

Mr. Banks in his Catalogue, 1910, places Herpyllus auratus Hentz as a Castianeira and in 1913, Mr. Emerton wrote a brief description and figured the female and the male palpus, the female was from Staten Island, N. Y. and the male from Falls Church, Virginia. This he calls Castianiera aurata Banks, not Hentz. (Bull. Amer. Mus. Nat. Hist., 22 : 258).

Micaria aurata is a misidentification and therefore a new name is necessary. I propose for it delicatula. According to Kaston, it is found in Connecticut. The only adult male in the collection at the Museum of Comparative Zoölogy is from the Sand Spit, Cold Spring Harbor, Long Island, N. Y. It differs from Micaria longipes Emerton with which has been synonomized, by the longer and more slender tibia of the palpus and the brilliant coloring. 


\section{FAMILY SALTICID $A$}

\section{SUBFAMILY HYLLINAE}

Genus Evarcha Simon 1902

Evarcha blanchardi (Scopoli)

Aranea blanchardi Scopoli, Ent. Carn., 1763, p. 402.

Attus hoyi Peckham, Descr. New or Little Known Spiders of the Fam. Attidae. 1883, p. 7, fig. 5, o

Attus pini id., ibid., p. 20, fig. 16, ㅇ

Hasarius hoyi Emerton, Trans. Conn. Acad., 1890, 8: 243, pl. 21, fig. 2.

Pellenes hoyi Peckham, Trans. Wisc. Acad., 1909, 16 : 557, pl. 48, fig. 4 .

Evarcha flammata Berland and Fage, Arach. France, 1937, 6 : 1240, 1270, figs. 2015, 2022.

In the revision of the Arachnides de France, 1937, 6 : 1271 , the authors in a footnote, mention that they have many specimens of this species from Georgia, Colorado and Oregon and that they are surprised that Peckham did not recognize and figure it in his last paper. Peckham did know it but he failed to identify it with the common European species. In fact, even in Europe, it has received many names, as the male and female are differently marked. Clerck, (1757), gave it two names, Scopoli called it blanchardi, Walckenaer, (1802 and 1805), added two more names, C. Koch, (1837) another, Hahn, (1831), still another, Simon, (1868) one more and Karsch, (1874) still another. It is found all over Europe and Siberia and here it is common from New England to Washington and south to Georgia. It also has been placed in several genera and in 1902, Simon erected the genus Evarcha for it.

\section{Subfamily Pellenin e}

Genus Habronattus F.O.P. Cambridge 1901.

Habronattus, F.O.P. Cambridge, Biol. Centr. Amer., 1901, 2: 241 .

Pellenes, Peckham, in part, nec Simon, Arach. France, 1876, 3: 90 .

The genus Pellenes was established by Simon in 1876, for Aranea tripunctata Walckenaer and Attus lapponicus 
Sundevall, both widely distributed species in Europe. Later, the first species was selected as the type of the genus.

Simon and Peckham exchanged specimens of the common species found in North America and France but Peckham did not recognize the genus Pellenes and he described most of the American species in the genus Habrocestum that he afterwards placed in the genus Pellenes. In 1900, he redescribed all the American species with the third leg longest under the genus Pellenes. A year later, F.O.P. Cambridge, who must have been familiar with the European species of Pellenes, erected the genus Habronattus for the species found in Central America that have the tarsus of the male palpus not elongate, but more or less circular and flattened, with the bulb also circular, with two processes, sometimes widely separated, the outer usually longer but both following the contour of the cavity; the posterior legs are very spinose and the third and fourth tibiæ have a small dorsal spine at the base. These characters are just opposite to the European species of Pellenes.

The genus Pellenes is described with the quadrangle of eyes a little wider behind, small eyes midway between first and third rows, anterior legs robust, third pair longest, posterior tibiæ always lacking a dorsal spine. In the European species, the palpus is elongate, bulb long, with the embolus arising from the prolateral margin about the middle and continuing on margin as a stout, heavy spine to the tip of the cavity. There are a few American species that have several characters in common with the European. They have a similar palpus, and the posterior tibiæ have no dorsal spine, but the first pair of legs is longer than the third pair and the patella is normal. Pellenes peninsulanus Emerton and $P$. longimanus Emerton belong to this group but neither have been found in New England.

The genus Habronattus has many species in America. Eight are known from New England. All have the third leg longest and several have modifications on the first and third pairs.

SUBFAMILY DENDRYPHANTINA

Genus Metaphidippus F.O.P. Cambridge 1901.

Metaphidippus, F.O.P. Cambridge, Biol. Centr. Amer., 1901, $2: 262$. 
Dendryphantes Peckham, in part; Simon, 1903, in part, nec Dendryphantes C. L. Koch.

The genus Dendryphantes was based by C. L. Koch, (1837) on Aranea pini DeGeer, (hastatus Clerck), a common species in Central Europe. It is strikingly unlike the American species that have been placed in that genus. Dendryphantes pini has the cephalic portion of the carapace broad and swollen, the quadrangle of eyes plainly wider behind than in front, the second row of eyes nearer the first than the third row, the p.l.e. not on extreme margin of the carapace, pubescence of scales, three pairs of ventral spines on the first tibia, basal, median and distal, that are small and opposite, palpus with tibia and patella of about equal length, tibial apophysis slender, straight and parallel to the cymbium, embolus arises on prolateral side about onequarter from the tip of the bulb, a long slender and slightly curved spine, almost half the length of the cymbium.

In 1901, F.O.P. Cambridge described the genus Metaphidippus basing it on the Mexican species mandibulatus and suggesting that the small species described by the Peckhams as Dendryphantes belonged to the genus. These have the lateral margins of the carapace almost parallel, certainly not swollen in the eye area, the quadrangle of eyes is the same width in front as behind, or in a few species only slightly wider behind, the second row of eyes is midway between the first and third rows, the p.l.e. is on the extreme margin of the carapace, pubescence of a few hairs, not scales, three pairs of ventral spines on the first tibia, restricted to the distal half or two-thirds, strong and not opposite, palpus with tibial apophysis a short, bent spur, embolus starts from the tip of the bulb, usually a broad, flat lobe, with lateral margins chitinized and prolonged in points beyond the middle area.

The genotype, mandibulatus has long, porrect mandibles in the male. Most of the American species have short, vertical mandibles in both male and female but the size and angle of the mandibles is a variable character among other genera of the Salticidx. All eastern species of the genus have no spines on the anterior patellae.

At the same time, F.O.P. Cambridge erected another genus, Paraphidippus and suggested that Attus marginatus 
Walckenaer, (militaris Hentz), belonged there. It is evident that he had never seen the species and knew it only from the description given by the Peckhams, although it has been reported from Mexico. In 1909, Peckham in his "Attidae of North America", places it in the genus Dendryphantes. It is not a true Metaphidippus as the small eyes are nearer the first than the third row, but it has more characters in common with Metaphidippus than with Paraphidippus.

Eight species of Metaphidippus have been found in New England. Probably the commonest is Metaphidippus capitatus (Hentz). The synonomy of this species is very unsatisfactory. A few of the names are given.

Attus capitatus Hentz, 1845, 5 : 200, pl. 17, fig. 15; reprint, p. 51, pl. 7, fig. 15.

Attus aestivalis Peckham, 1883, p. 2, fig. 2.

Icius crassiventer Keyserling, Verh. z. b. Ges. Wien, 1884, 34 : 503, pl. 13, fig. 11.

Dendryphantes aestivalis Emerton, Trans. Conn. Acad., 1891, $8: 228$, pl. 17, fig. 2.

Dendryphantes capitatus Peckham, Trans. Wisc. Acad., 1909, $16: 469$, pl. 36, fig. 4 , pl. 38, fig. 5 .

Hentz described capitatus from a single male collected in Georgia and on the plate, he failed to place a line next the figure to indicate the length, so it can be inferred that the drawing is the natural size. If this inference is correct, capitatus is probably a Phidippus and not found in New England as all the specimens found here are small. However, the male and female are marked differently and Hentz described several other species that are common in the south that would agree very well with the females collected in New England.

Attus aestivalis is described by the Peckhams, from a pair collected in Pennsylvania. Unfortunately the types are missing from the Peckham Collection in the Museum of Comparative Zoology, and neither can be found in the collection any specimens named by them. The figure of the palpus shows two dark, sinuous processes at the tip of the bulb but the processes are not connected. The figure of the epigynum is also rather indefinite, but the description states a "rounded opening at the posterior edge". The length of the 
lateral margins on the embolus and the shape of the opening of the epigynum are of specific importance.

The type of Icius crassiventer Keyserling is a female, from Massachusetts and is in the museum collection. It agrees with what has been called Dendryphantes capitatus.

\section{SUBFAMILY SITTICINAE}

Genus Sitticus Simon 1901

\section{Sitticus pubescens (Fabr.) (Fig. 2)}

Attus pubescens Fabricius, Syst. Ent., 1775, p. 438.

Sitticus pubescens Berland and Fage, Arach. France, 1937, 6 : 1186, 1255, figs. 1869, 1871.

Male. Length, $4.8 \mathrm{~mm}$., ceph. $2.2 \mathrm{~mm}$., abd. $2.0 \mathrm{~mm}$.

Cephalothorax a very dark brown, cephalic portion with scattered short, white hairs most numerous about p.l.e. and forming a white spot about the middle of the eye area, cephalic portion high, ending a short distance posterior to the third eye row with a shallow depression, eye area flat, thoracic groove short and deep, thoracic portion much longer and wider than cephalic, with rounded sides, in about the same plane as the cephalic until the posterior third when it slopes rapidly to the margin; eye area about two-fifths the length of the cephalothorax, wider in front, anterior row of eyes strongly recurved, eyes equidistant, row of long hairs above a.m.e., eyes of second row nearer first than third row, third row not as wide as cephalothorax and eyes smaller than a.l.e.; clypeus below a.m.e. about a radius of a.m.e.; mandibles rather small, vertical, flat in front, fang groove slightly oblique with four subequal teeth closely grouped on superior margin, inferior margin not defined but an oblique row of bristles from base of fang to median margin, fang with a wide base and evenly curved; sternum dark brown with white hairs about posterior margin, convex, anteriorly little wider than labium, fourth coxæ almost touching; abdomen dark brown thickly covered with white and fauncolored hairs arranged in no definite pattern, venter paler; legs, 4-1-2-3, yellowish-brown with many short white hairs, femora clouded with dark brown, anterior tibiæ with broken basal and distal dark rings, tips of tarsi dark, all joints of 
fourth leg longer than corresponding joints of first leg; spines, no spines on patellæ, I pair, tibia, ventral, 2-2-2, lateral, 0 , metatarsus, ventral, 2-2, lateral, 0 ; palpus dark, terminal joint thickly covered with long, coarse hairs, femur curved at base and laterally compressed, seen from above,

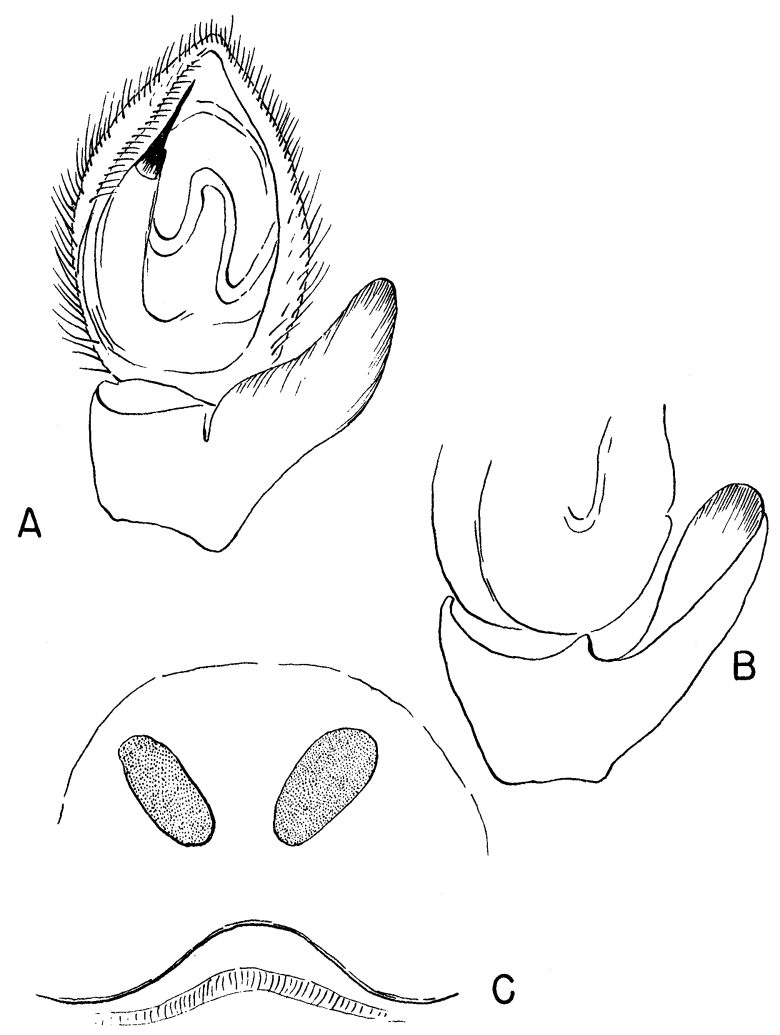

Figure 2. Sitticus pubescens (Fabr.). A, ventral view of palpus; B, tibial apophysis; C, epigynum.

patella and tibia subequal, tibial apophysis a large spoonshaped lobe, longer than diameter of the joint, starting from the base of the joint and directed forward and slightly outward, not pressed against the tarsus and almost reaching the middle of that joint, on opposite side of the tibia a row of 
long black hairs, cavity extends length of the cymbium and filled with the palpal organ, bulb divided longitudinally, larger half shows duct of two loops in upper portion, smaller half with the rather short, straight embolus that starts at distal end with a short tooth near origin and tip near the end of cavity.

Female. Length, $4.9 \mathrm{~mm}$., ceph. $2.0 \mathrm{~mm}$., abd. $3.0 \mathrm{~mm}$.

Cephalothorax dark brown, eye area black with a sparse covering of short white hairs, no median white spot as in the male but the same fringe of long black hairs above a.m.e., thoracic groove wanting; eyes, anterior row not as strongly recurved as in the male; mandibles, superior margin with five teeth, no oblique row of bristles on inferior margin as in the male; abdomen black with white and faun-colored hairs forming a pair of large white spots about the middle, followed by three pairs of very small dots, venter paler; legs and spines same as in male; epigynum, margin of fold distinctly notched and at some distance above, a pair of black oblique oval sacs beneath the skin.

of \& Massachusetts; Allston, 14 July 1932.

of $\&$ Massachusetts; Allston in house, 15 July 1934.

This species is found throughout Europe and according to modern authors, it is subject to variations in color pattern and shape of the tibial apophysis of the male palpus and even the longitudinal division in the palpal organ. The museum collection has a male from the Paris Museum and a pair from the Peckham Collection, probably received from Simon. The male from the Paris Museum has the same large spoon-shaped tibial apophysis, the palpal organ with the longitudinal division but the embolus is half hidden, so that it is impossible to see if it has a tooth near its origin. The superior margin of the fang groove has three unequal teeth as figured by Simon in the Histoire Naturelle des Araignées, $2: 578$, fig. 699 ; figure 700 on the same page shows the large spoon shaped tibial apophysis but the ambolus is a long slender tube, starting on the margin about the middle on the same side as the apophysis, (retrolateral), something that is not mentioned in any description of the species. According to Simon and Reimoser, it has received several names, which is not surprising from the variations 
in marking and habitat. Simon states in Arachindes de France, 1876, 3 : 108, "Commun dans toute l'Europe; il se trouve ordinairement sur les murailles exposées au soleil, même dans l'intérieure des villes".

A pair was found on a brick wall in the sun on a very hot morning in July 1932. Two years later on almost the same date, a pair was taken inside the house jumping on a window screen. In movements, it suggests Salticus scenicus. 

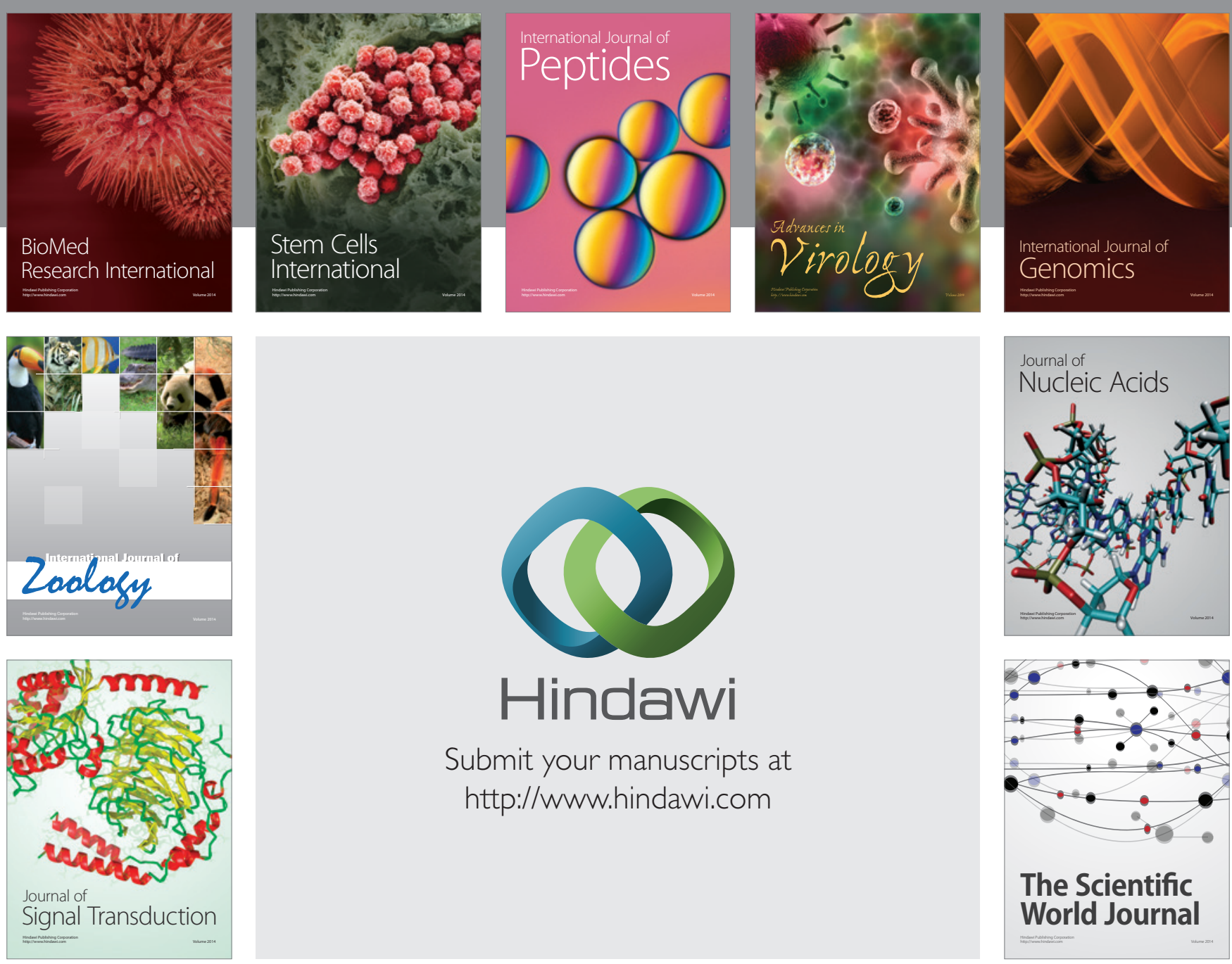

Submit your manuscripts at

http://www.hindawi.com
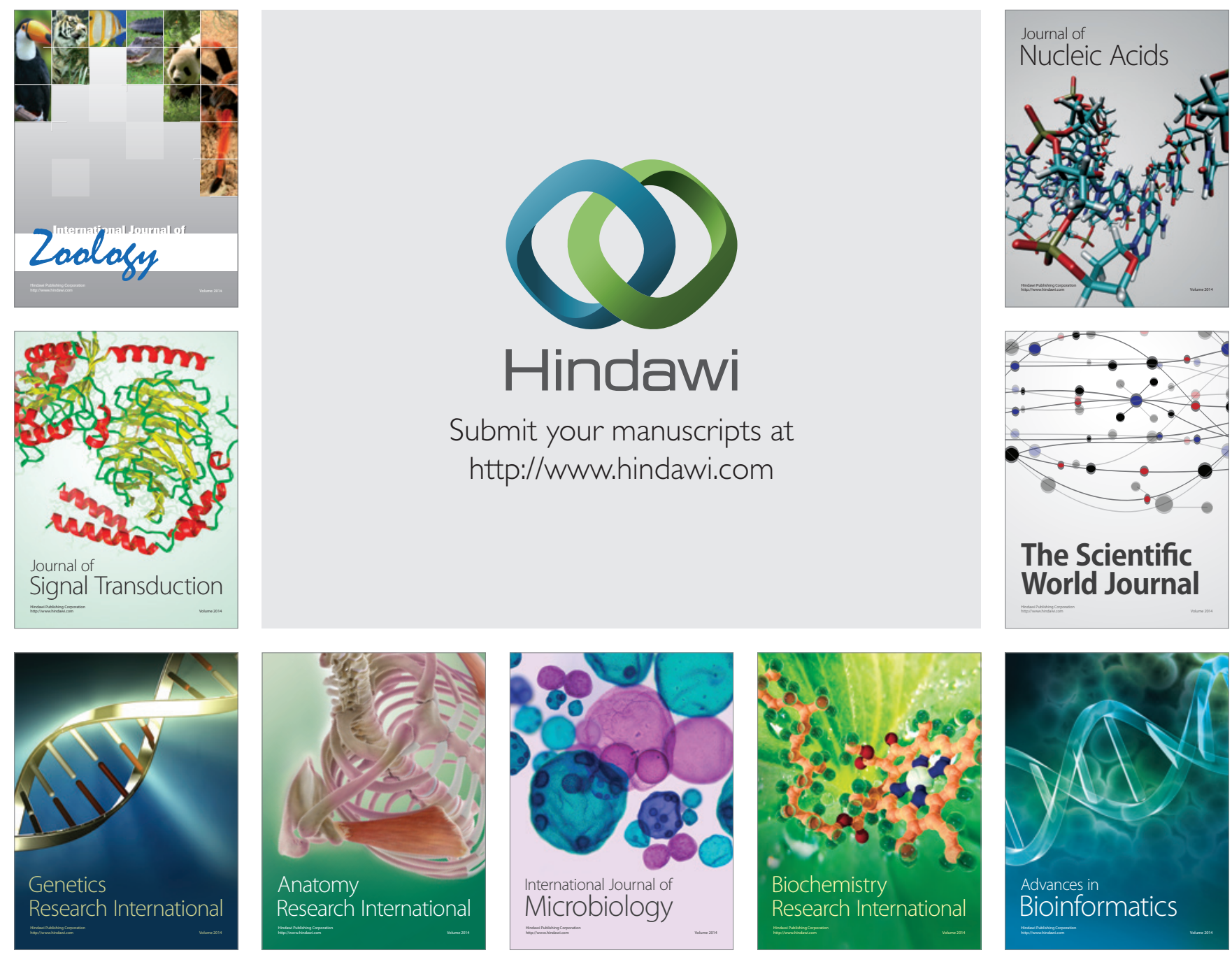

The Scientific World Journal
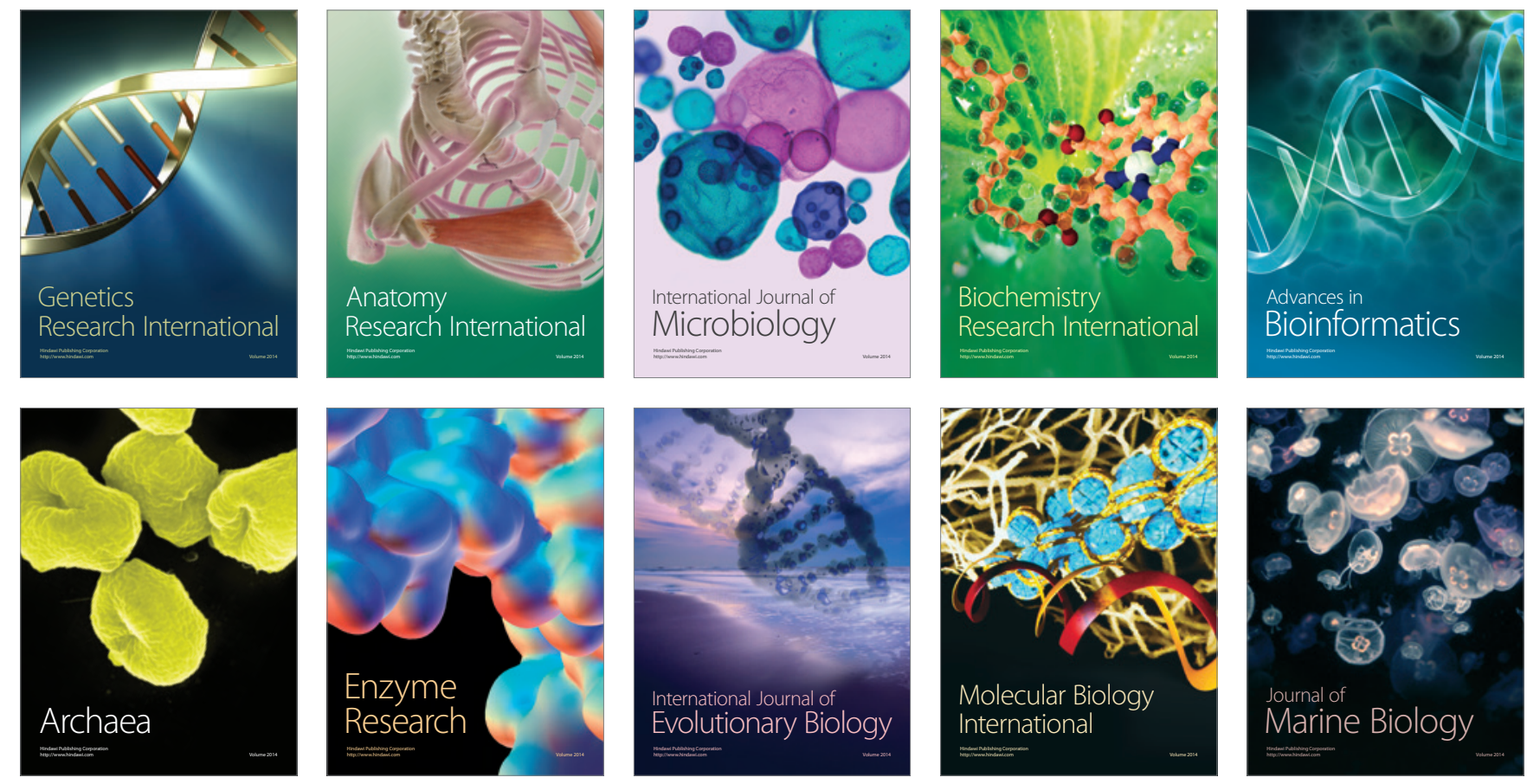